\section{On the Binding of Gelatine to Modified Serum Proteins Through Formaldehyde in an Experimental Blood Volume Expander}

The preparation, in our Institute, of an experimental blood volume expander from bovine serum includes heat denaturation, formolation and an oxidation of serum proteins in the presence of a partially degraded gelatine $(\mathrm{PDG})^{1}$. In the present study we tried to get information whether, and to what extent, the formation of intermolecular methylene links ${ }^{2-4}$ takes place between serum proteins and PDG under the given conditions.

The experimental approach consisted in the separation and determination of bound and free PDG in the following standard samples. Sample A: a mixture of 4 volumes of bovine serum ( $5 \%$ protein) and of 1 volume of $4 \%$ PDG was heated at $100^{\circ} \mathrm{C}$ for $1 \mathrm{~h}$ at $\mathrm{pH} 8.5$ in the presence of $0.13 \%$ formaldehyde. Sample B was prepared by oxidizing sample A by $1 \%$ hydrogen peroxide at $90-95^{\circ} \mathrm{C}$ for $10 \mathrm{~min}^{1}$. Sample C: to $4 \mathrm{Vol}$ of $5 \%$ bovine serum formolated previously without gelatine in the same way as sample A, 1 Vol of 4\% PDG was added afterwards at laboratory temperature. Sample $D$ was a simple mixture of $4 \mathrm{Vol}$ of $5 \%$ serum and $1 \mathrm{Vol}$ of $4 \%$ PDG.

Gel filtration on Sephadex G-200 was used to separate the free low-molecular PDG (consisting of particles of m.w. 10,000-15,000 $)^{5}$ from the main high-molecular fraction of the modified serum (with particles of an average m.w. 100,000-150,000 ${ }^{5}$, to which a part of PDG was assumed to be bound through formaldehyde. The amount of bound PDG was then estimated by comparing the contents of hydroxyproline ${ }^{6}$ in each sample before the gel filtration (this value was taken as $100 \%$ ) and in the separated high-molecular fraction of the corresponding sample. Thus the samples A, B, C, and D contained bound PDG in ratios of $60 \%, 45 \%, 35 \%$, and $0 \%$ respectively. These results, even though only semi-quantitative, still indicated a significant binding of PDG to modified serum proteins.

More accurate quantitative results, however, were achieved by another method 7 based on the precipitation of serum proteins together with bound PDG by $5 \%$ trichloroacetic acid. Free PDG which remained in solution during this operation was then determined turbidimetrically or densitometrically after reaction with tannin at $\mathrm{pH}$ 4.9. The content of free and bound PDG in the samples tested was expressed in $\%$, taking sample $\mathrm{D}$ as having $100 \%$ PDG free, i.e. $0 \%$ of PDG bound to serum proteins. The results are presented in the Table. The standard deviations of the mean were calculated for $P=0.05$.

The results shown in the Table confirm the existence of the intermolecular binding mentioned above, and they can be taken as an indirect proof of the formation of methylene links between the other protein molecules of blood volume expanders of this kind, as had been assumed. On oxidation (sample B) a part of bound PDG was released, probably because of the rupture of some bonds under the formation of formic acid ${ }^{2,8}$.

Binding of gelatine to serum proteins in different samples

\begin{tabular}{ll}
\hline Sample & $\begin{array}{l}\% \text { of } \\
\text { bound } \\
\text { gelatine }\end{array}$ \\
& \\
\hline A (serum + gelatine, formolated) & $34.9 \pm 3.1$ \\
B (sample A - oxidized) & $18.8 \pm 2.6$ \\
C (serum formolated, gelatine added afterwards) & $5.5 \pm 3.8$ \\
D (serum + gelatinc) & 0
\end{tabular}

Zusammenfassung. Beim Formolieren und Erhitzen einer Mischung von Rinderserum und teilweise abgebauter Gelatine wird ein Teil der Gelatine kovaliert an die Moleküle des bei diesem Prozess modifizierten Serums gebunden. Die Trennung der noch freien von der an die Serumproteine gebundenen Gelatine konnte durch Gelfiltration mit Sephadex G 200 und durch fraktionierte Fällung mit Trichloressigsäure erreicht werden.

\section{T. I. PŘISTOUPIL.}

Institute of Hematology and Blood Transfusion, Praha (Czechoslovakia), November 9, 1964.

I J. Nikl and T. I. Přistoupil, Czech. Pat. No. 89802 (1959).

2 I. SyrovÝ and T. I. Pǩistoupil, Čs. farmacie 10, 292 (1961).

3 A. Engelhardt, Arztl. Praxis 5, 21 (1953)

4 R. ARdry and G. Elie, Bull. Soc. Chim. Biol. 38, 129 (1956).

5 T. I. P光istoupil, J. Chromatogr., in press.

6 R. E. Neuman and M. A. Logan, J. biol. Chem. 184, 299 (1950).

7 T. I. Přstroupil, V. Tomanová, and J. NikL, Chem. listy 50,387 (1956).

8 The technical assistance of Mrs. Z. NovotNÁ is gratefully acknowledged.

\section{A Study of DNA Synthesis in Sea Urchin Hybrids by the Incorporation of $\mathbf{H}^{3}$-Thymidine}

In our previous studies 1,2 we have followed the incorporation of $\mathrm{C}^{14}$-adenine into RNA during the development of both normal and hybrid sea urchin embryos. The present paper deals with a similar study on the synthesis of DNA by using $\mathrm{H}^{3}$-thymidine as the precursor.

The hybrids studied were Paracentrotus $q \times$ Arbacia 0 (PA) and Paracentrotus ㅇ $\times$ Sphaerechinus of (PS). Both combinations die similarly at the early gastrula stage but are quite different in their cytological behaviour ${ }^{3-5}$. It would be of interest to know if and how they differ in their ability to take up labelled precursors into DNA Tritiated thymidine has been shown to be incorporated in the nuclei of amphibian hybrids ${ }^{6,7}$. Analyses of DNA

1 P. S. Chen and F. Baltzer, Exper. 18, 522 (1962).

2 P. S. Chen and F. BALtzer, Exper, 20, 236 (1964).

3 A. H. Whiteley and I'. Baltzer, Pubbl. Staz. Zool. Napoli 30, 402 (1958).

${ }^{4}$ F. BaLtzer, Arch. Zellf. 5, 497 (1910).

5 F. Baltzer and P. S. Chen, Rev, suisse Zool. 67, 183 (1960),

6 R. 'Tencer, Nature 190, 100 (1961).

7 B. C. Moore, Ann. Histochim. 9, 264 (1963). 